\title{
FUZZY-LOGICAL EXPERT SYSTEM FOR ASSESSING THE FINANCIAL SECURITY OF ENTERPRISES
}

\author{
Valentin Myachin ${ }^{1}$, Olena Yudina ${ }^{2}$, Oleksandr Myroshnychenko ${ }^{3}$
}

\begin{abstract}
The purpose of this study is to build a fuzzy expert system for assessing the financial component of the economic security of telecommunications enterprises. The methodological basis of the research is founded on scientific works of domestic and foreign scientists and leading experts in the field of financial analysis and modeling of economic processes, as well as statistical and financial reporting data that are publicly available. To construct an integral indicator of the financial security of an enterprise, a fuzzy conclusion is used. Three financial indicators are used as input variables. The first indicator $X 1$ is the Current Ratio (CR). The second indicator $X 2$ is Equity Ratio (ER). The third indicator is Return on Assets (ROA). The output variable is defined as an indicator of the financial security of an enterprise Y123 (FS). Both the input variables and the output variable are converted to fuzziness by constructing membership functions. The type and parameters of the affiliation function are justified, and the bellshaped affiliation function is chosen to describe the uncertainty of values that fall under the normal distribution. The quantity of fuzzy sets at every input is considered as $z=3$ and the quantity of input variables is considered as $\omega=3$. To achieve completeness of the model, the quantity of logic rules is considered as $r=3^{3}=9$. To calculate a degree of market concentration, Mamdani fuzzy conclusion is applied. Defuzzification is engaged to calculate the value of the output variable Y123(FS) for an indicator that determines the degree of financial security of an enterprise and, as a result, the degree of its economic security. To assess the level of the financial security indicator of an enterprise, a fuzzy expert system is constructed. The fuzzy expert system allows you to use various indicators thanks to the fuzzy logic methodology, which takes into account the fuzziness of input variables and output variables as much as possible. For the three telecommunications companies whose core business is wireline communication, ratios are calculated based on financial reports. Financial coefficients are used to determine the integral indicator of financial security of enterprises. This indicator can be characterized by both numerical values and linguistic terms.
\end{abstract}

Key words: financial security of the enterprise, integral indicator, fuzzy expert system, fuzzy logic, membership function, defuzzification, Current Ratio (CR), Equity Ratio (ER), Return on Assets (ROA).

JEL Classification: G32, D81

\section{Introduction}

In modern conditions, participants in economic activity often have an objective need to obtain truthful information about the probability of bankruptcy and financial security of the enterprise. Relevant information and its evaluation can be obtained in various ways. One of the ways to obtain such information is to analyze the financial condition of the enterprise. Its main goal is to timely clarify and eliminate shortcomings in the financial efficiency of the enterprise's economic activities.

Enterprises of the telecommunications industry also need to develop practical tools focused on analyzing and monitoring both the financial condition and security. To assess the financial condition of an enterprise, including a telecommunications enterprise, a regulatory approach is used. The regulatory approach consists in comparing the calculated financial

\footnotetext{
Corresponding author:

${ }^{1}$ Ukrainian State University of Chemical Technology, Ukraine .

E-mail: myachin2020fuzzy@gmail.com

ORCID: https://orcid.org/0000-0002-1491-5100

ResearcherID: https://publons.com/researcher/4351259/valentin-myachin

${ }^{2}$ Private Institution of Higher Education "Dniprovskii University of the Humanities", Ukraine.

E-mail: el.judina@gmail.com

ORCID: https://orcid.org/0000-0003-3699-5321

ResearcherID: https://publons.com/researcher/4350920/olena-yudina

${ }^{3}$ Ukrainian State University of Chemical Technology, Ukraine.

E-mail: ardenalexx@gmail.com

ORCID: https://orcid.org/0000-0002-7106-5632
} 
indicator with its regulatory value approved by law or, accordingly, with methodological recommendations adopted in the company itself.

But standards or calculation algorithms approved by law often use methods introduced into the practice of financial analysis more than half a century ago, when there were no modern methods of in-depth data processing (Data Mining). For this reason, classical models for estimating financial condition, in particular, the evaluation of bankruptcy of an enterprise, can give a distorted assessment. In addition, many indicators of financial analysis do not have a clear rationing and largely depend on the field of activity of the enterprise.

A typical telecommunications enterprise is a complex socio-economic system that operates in conditions of significant uncertainty in the internal and external environment. Improving the efficiency of management decision-making in the administration of the telecommunications enterprise to a large extent can be provided by tools based on methods and models of fuzzy production systems.

\section{Modern methods for assessing the level of financial security of an enterprise}

The need to know the current financial condition of the enterprise and maintain its proper level in market competition causes the need to develop modern methods for assessing the level of financial security of the enterprise. In the theory and practice of financial analysis, there are a significant number of methods that are used to determine the level of financial security of business entities.

In the course of the analysis of professional literature (Korpan, 2017; Kampo, Dochynets \& Havrylets, 2017; Yelisieieva \& Simon, 2016), it was determined that methods for determining the level of financial security of the enterprise can be based on: the study of cash flows, the definition of financial indicators-indicators, assessing the financial stability of the enterprise, methods of predicting bankruptcy, the definition of integral indicators and resourcefunctional approach.

The approach based on the study of cash flows is due to the fact that the indicator of net cash flow is one of the indicators of the economic performance of the enterprise and determines its financial condition. But this approach is a narrow approach, since it does not cover all areas that affect the state of financial security of the enterprise (Herasymenko \& Holovach, 2003).

The indicator approach involves comparing the actual values of financial security indices with the limiting values of the indicators of its level. This approach achieves the highest level of financial security of the enterprise, provided that the entire set of indicators is within the threshold values, and the threshold value of each indicator is not to the detriment of the others and has a justified financial approach. This method should be recognized as appropriate and reasonable, but its disadvantage is that the use of this approach depends mainly on determining the threshold values, which depend on the state of the external environment, on which the company is unlikely to affect, but only to adapt to its conditions (Hladchenko, 2001).

Kampo H., Dochynets N. and Havrylets O. propose to evaluate the level of economic security financial component of the enterprise based on the analysis of its financial stability, the degree of which is determined in terms of sufficiency of working capital (own or borrowed) to carry out production and marketing activities (Kampo, Dochynets \& Havrylets, 2017). This is a narrow perspective in assessing the level of financial security of an enterprise. In addition to working capital, the enterprise's financial activity involves its own fixed capital, profits, investments, securities, etc.

Integral models for estimating the probability of bankruptcy include the well-known models of E. Altman (Altman, 1968), R. Taffler and H. Tishaw (Toffler \& Tishaw, 1977). Parshyna O., Myachin V. and Kutsyns'ka M. presented a detailed overview of existing integrated models (Parshyna, Myachin \& Kutsyns'ka, 2016; Myachyn \& Kutsyns'ka, 2015). To date, Ukrainian scientists have already developed models such as the discriminant model for the integral assessment of enterprise financial condition (Tereshchenko, 2004). This model is based on the application of the methodology of discriminant analysis based on financial indicators of a sample set of domestic enterprises and a comprehensive assessment of the financial condition of the enterprise. This evaluation method allows you to identify trends in the dynamics of the financial condition of the enterprise.

Krakos Yu. and Razgon R. recommend considering the financial security of an enterprise as a complex value, since it examines several components, in particular, the efficiency of enterprise management, solvency and financial stability, business and market stability, investment attractiveness (Krakos \& Razghon, 2008).

Another method for assessing the level of financial security is considered within the framework of the resource-functional approach, according to which it is proposed to evaluate each functional component of financial security, and then determine the integral indicator by expert means.

Another method for assessing the level of financial security is considered within the framework of the resource-functional approach, according to which it is proposed to evaluate each functional component of financial security, and then determine the integral indicator by expert means. With this approach, the functional structure of financial security of an enterprise is determined by the following components: 
budget; monetary; currency; banking; investment; stock; insurance (Blank, 2016).

Despite the overwhelming preference of scientists for the expert method in determining the weight of individual functional safety components, some authors modify the method of determining the weight of components into an overall integral index. This indicates that there is no single position of scientists in the formation of methods for assessing the financial security of enterprises.

\section{Justification of the levels of financial coefficients in the model of constructing an integral indicator of financial security of an enterprise}

To build an integral indicator of enterprise financial security, we highlight the following algorithm of actions:

- selection of the financial analysis information base;

- formation of groups of financial coefficients;

- determination of the algorithm for calculating financial coefficients;

- determination of the standard values of the coefficients for each group of ratios;

- formation of a mechanism for assessing the financial security of the enterprise.

The indicators involved should be, on the one hand, the most representative, but, on the other hand, their number should be limited enough not to overload the mathematical model.

To form groups of estimated coefficients, first of all, we will use the opinion of such authors as Yelisieieva O. and Simon H. (Yelisieieva \& Simon, 2016), Sosnovska O. (Sosnovska, 2019), Diyazitdinova A. and Saprykina A. (Diyazitdinova \& Saprikina, 2018), Starinets O. (Starynets, 2018), who study the financial condition of telecommunications enterprises.

Liquidity is the ability to convert assets into cash in the shortest possible time, with minimal costs and without losing their value. Thus, the characteristics of liquidity are: 1) absolute values of assets and cash; 2) conversion time (Korpan, 2017).

Current liquidity ratio (other names - Level 1 liquidity; total liquidity ratio; Coverage Ratio, Current Ratio (CR)) shows the relationship between the size of current assets and current liabilities; shows the ability of an enterprise to repay current (short-term, up to one year) liabilities only at the expense of current assets.

The formula for calculating the Current Liquidity Ratio $(C R)$ is as follows:

$$
C R=\frac{\text { Current Assets }}{\text { Current Liability }}=\frac{\text { line code } 1195}{\text { line code } 1695} \text {. }
$$

The current liquidity ratio represents a general view of the company's liquidity and is the starting point for its further analysis. This ratio allows us to check whether all assets with a turnover period of less than one year can cover liabilities with a maturity period of less than one year (Chaika, Loshakova \& Vodoriz, 2018).

According to the traditional approach, the higher the current liquidity ratio, the more liquid the enterprise is. However, too high $C R$ values are not an absolute advantage, since they can be associated with inefficient use of current assets and/or short-term liabilities. A value of $C R<1$ indicates decapitalization of the company and insufficient short-term solvency. The value of $C R>2$ is associated with inadequate management of current assets.

Diyazitdinova A. and Saprikina A. for telecommunications enterprises offer a standard value of the current liquidity ratio of more than 0.75 . Moreover, these authors recommend a range of values for this coefficient of $2.0 \ldots 2.5$ and characterize it with the linguistic term "very high", they characterize a figure in the range 1.0...2.0 as "high", a value in the range $0.75 \ldots 1.0$ as "average", "low" corresponds to a $0.25 \ldots 0.75$ value, "very low" is equal to a value of 0.0...0.25 (Diyazitdinova \& Saprikina, 2018).

Starinets O. for telecommunications enterprises suggests taking the current liquidity ratio $>1$ as the standard value (Starynets, 2018).

Effective management of the financial stability of the enterprise allows the enterprise to better adapt to environmental conditions and control its dependence on external sources of financing. Financial stability is one of the main factors influencing the achievement of financial equilibrium and financial stability by an enterprise (Voloshchuk, 2015).

The financial stability coefficient allows you to determine how much of the assets are financed from long - term sources of financing-equity and longterm borrowed financial resources. A high value of the indicator shows a low level of risk of solvency loss and good prospects for the functioning of the enterprise.

The formula for calculating the Margin of Safety $(\mathrm{MoS})$ coefficient is as follows:

$$
\begin{aligned}
& \text { MoS }=\frac{\text { Equity }+ \text { Non }- \text { Current Liability }}{\text { Balance Sheet Liability }}= \\
& =\frac{\text { line code } 1495+\text { line code } 1595}{\text { line code } 1900} .
\end{aligned}
$$

Sosnovska O. for communication Enterprises offers the optimal value of the financial stability coefficient in the range of $0.7 \ldots 1.0$ (Sosnovska, 2019).

Davydenko N. proposed a linguistic description of the different values of the financial stability coefficient. This author offers a point-based method for assessing financial stability (solvency). The value of the indicator within $0.8 \ldots 0.9$ is the most optimal and is characterized by the author's linguistic term as 
"normal", the value of the indicator within $0.4 \ldots 0.8$ is characterized by the linguistic term as "critical", the value of the indicator within $0.0 \ldots 0.4$ is characterized by the linguistic term as "below the critical" (Davydenko, 2017).

Kampo G., Dochynets N. and Havrilets O. note that the standard value of the financial stability coefficient is $0.7 \ldots 0.9$. According to their data, the value of the financial stability coefficient for telecommunications industry enterprises in 2012, 2013, 2014 and 2015 was $0.560,0.556,0.361$ and 0.631 , respectively, which is outside its standard value (Kampo, Dochynets \& Havrylets, 2017).

It should be noted that if the company does not have long-term obligations, the MoS financial stability coefficient is transformed into the Equity Ratio (ER).

The formula for calculating the coefficient of financial autonomy or financial independence (Equity Ratio (ER)) has the following form:

$$
E R=\frac{\text { Equity }}{\text { Balance Sheet Liability }}=\frac{\text { line code } 1495}{\text { line code } 1900} \text {. }
$$

Sosnovska O. for communication Enterprises offers the optimal value of the coefficient of financial independence (autonomy) in the range of $0.5 \ldots 1.0$ (Sosnovska, 2019).

Diyazitdinova A. and Saprikina A. propose six financial coefficients for evaluating the financial condition of telecommunications enterprises. Among them, the authors propose to use the autonomy coefficient, which is recognized as the share of own funds in total assets. These authors recommend a range of normative values in the range of $0.5 \ldots 0.75$ and characterize it with the linguistic term "high". The value of the indicator in the range of $0.25 \ldots 0.375$ was described by them as "very low" and "low", and the value of the indicator in the range of $0.375 \ldots 0.50$ was described as "average" (Diyazitdinova \& Saprikina, 2018).
Return on Assets (ROA) shows the efficiency of using the company's assets to generate profit. A high value of the indicator indicates the good performance of the enterprise. It is calculated as the ratio of net profit (or net loss) received to the average annual amount of assets. Information about the value of assets can be obtained from the balance sheet, and information about the amount of net profit can be obtained from the statement of financial results (income statement).

The formula for calculating the Return on Access (ROA) ratio is as follows:

$$
R O A=\frac{\text { Net Income }}{\text { Total Assets }}=\frac{\text { line code } 2350}{\text { line code } 1900} .
$$

There is no single standard value for the indicator $R O A$. It should be analyzed in dynamics, that is, comparing the values of different years for the study period. In addition, you should compare the value of the indicator with the figures of direct competitors (who have the same amount of assets or income). The higher the indicator, the more efficient the entire management process is, because the return on assets indicator is formed under the influence of all the company's activities.

Sosnovska O. offers the optimal value of the return ratio on total assets (total capital) in the range of $0.05 \ldots 1.0$ for communication enterprises (Sosnovska, 2019). Starinets O. considers the coefficient of return on total assets $>0$ to be the standard value for telecommunications enterprises, and the dynamics of this coefficient should be directed towards growth (Starynets, 2018).

The final result of the study of financial coefficients is the determination of an integral indicator for assessing the level of financial security of telecommunications enterprises $Y 123(F S)$. A necessary condition is the gradation of enterprises' financial security levels, which is presented on the basis of using the method of expert assessments and a review of literature sources

Table 1

Characteristics of financial security index (FS) levels of telecommunication enterprises

\begin{tabular}{|c|l|l|}
\hline $\begin{array}{c}\text { Linguistic description } \\
\text { of enterprise economic } \\
\text { security levels }\end{array}$ & $\begin{array}{c}\text { Thresholds of enterprise } \\
\text { economic security levels }\end{array}$ & Characteristics of the company according to the established level of financial security \\
\hline High (excellent) & $0,70<Y 123(F S) \leq 1,00$ & $\begin{array}{l}\text { It indicates the existence of effective risk management methods, which are the result of } \\
\text { adaptation to unstable economic conditions and minimizing threats to the economic } \\
\text { activity of the enterprise. This level of financial security ensures the stable functioning } \\
\text { of the enterprise in an uncertain economic environment. }\end{array}$ \\
\hline Medium (satisfactory) & $0,30<Y 123(F S) \leq 0,70$ & $\begin{array}{l}\text { It indicates the presence of a moderate or acceptable influence of internal and external } \\
\text { environment risks on the likelihood of obtaining a negative financial result and } \\
\text { disruption of the enterprise's sustainable functioning. }\end{array}$ \\
\hline Low (unsatisfactory) & $0,00 \leq Y 123(F S) \leq 0,30$ & $\begin{array}{l}\text { This level of financial security is characterized by a violation of the financial condition } \\
\text { of the enterprise and its stable functioning, as well as inefficiency in the risk } \\
\text { management process. }\end{array}$ \\
\hline
\end{tabular}




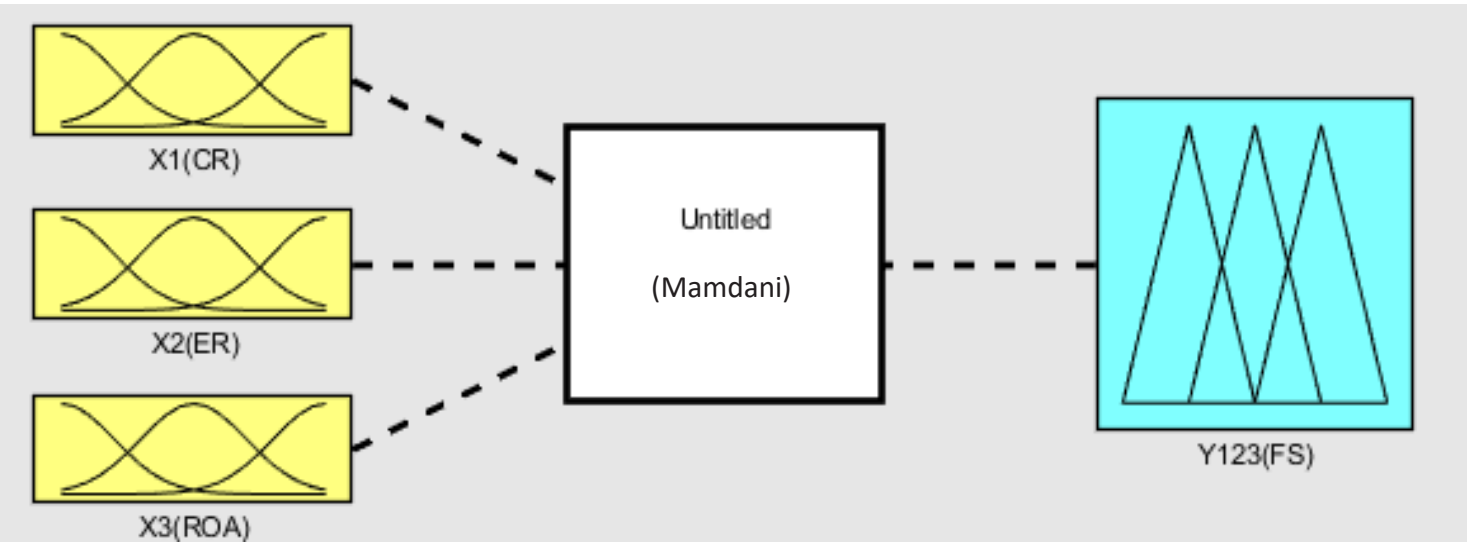

Figure 1. General structure of the Fuzzy-Logic System constructor

(Table 1) (Korpan, 2017; Sosnovska, 2019; Diyazitdinova \& Saprikina, 2018).

\section{Development of a fuzzy-logic expert system for measuring the financial security indicator of telecommunications enterprises}

Figure 1 introduces the general structure of the fuzzy logic expert system constructor as a data transformation within the system itself. For a fuzzylogical approach to determine the integral Financial Security (FS)) indicator Y123 of an enterprise, we have selected three input indicators that affect the target indicator, namely: Current Ratio X1(CR), Equity Ratio X2(ER) and Return on Assets Ratio X3(ROA).

Next phase of the fuzzy expert system construction is based on membership function selection. A fuzzy model makes the system quite difficult if it is based on a significant number of input variables, and therefore the number of input variables requires a reasonable optimal reduction (Korol, 2012).

To build a fuzzy expert system, we chose a bellshaped membership function, which visually looks like a symmetric curve and resembles the shape of a bell. This function is set by the formula which parameters are interpreted as follows:

$$
\mu(x)=\frac{1}{1+\left|\frac{x-c}{a}\right|^{2 b}},
$$

where $a$ - concentration ratio of the membership function; $b$ - curvature ratio of the membership function; $c$ - maximum coordinate of the membership function (Pegat, 2009).

Next phase of the fuzzy model construction is the identification of fuzzy logic rules. Considering that quantity of the model inputs (input variables) is $\omega$ and every input has $\mathrm{z}$ of fuzzy sets (membership functions) then the quantity of fuzzy logic rules can be defined through the following formula:

$$
r=z^{\omega} \text {. }
$$

Table 2 introduces correlation between the quantity of the model fuzzy rules which secure model completeness and model inputs (input variables) $\omega$ as well as the quantity of $z$ fuzzy sets in every input.

The quantity of fuzzy sets at every input is considered as $z=3$, the quantity of input variables is considered as $\omega=3$. Then the quantity of fuzzy logic rules should result in $r=3^{3}=27$ to secure the model completeness.

Modelling of a degree of financial security indicator has been executed in in FuzzyLogic Toolbox software of Matlab environment (version R2021A) by MathWorks company which has affected setting and view of the bell-shaped membership function. The setting of the function is as follows: $\mu(\mathrm{x})=\operatorname{gbellmf}\left(x,\left[\begin{array}{lll}a & b & c\end{array}\right]\right)$. $x$ is an input variable, $a, b$ and $c$ are aforementioned parameters (formula (3)).

Next figures 2-4 introduce attributes and membership functions for three input variables and one output variable. Figure 2 introduces $X 1(C R)$ input variable which is a Current Ratio and has three attributes (membership functions): Low - (unsatisfactory)

Table 2

Correlation between the quantity of the model fuzzy rules which secure model completeness and model inputs (input variables) $\omega$ as well as the quantity of $z$ fuzzy sets in every input

\begin{tabular}{|c|c|c|c|c|c|}
\hline \multirow{2}{*}{$\begin{array}{c}\text { Quantity of } z \text { fuzzy } \\
\text { sets at every input }\end{array}$} & \multicolumn{5}{|c|}{ Quantity of the model $\omega$ inputs (quantity of the input variables) } \\
\cline { 2 - 6 } & $\omega=1$ & $\omega=2$ & $\omega=3$ & $\omega=4$ & 1 \\
\hline$z=1$ & 1 & 1 & 1 & 16 & 1 \\
\hline$z=2$ & 2 & 4 & 8 & 81 & 243 \\
\hline$z=3$ & 3 & 9 & 27 & 243 \\
\hline
\end{tabular}




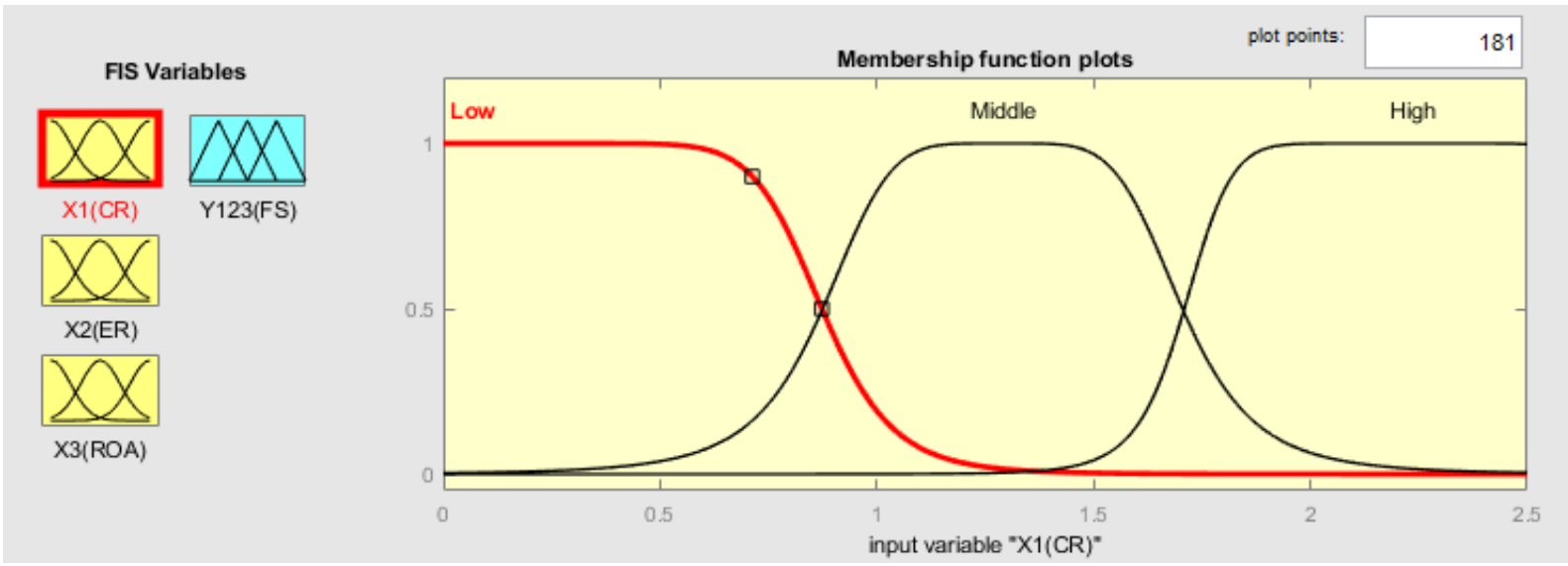

Figure 2. Membership function chart for input linguistic variable X3 ("Current Ratio (CR)")

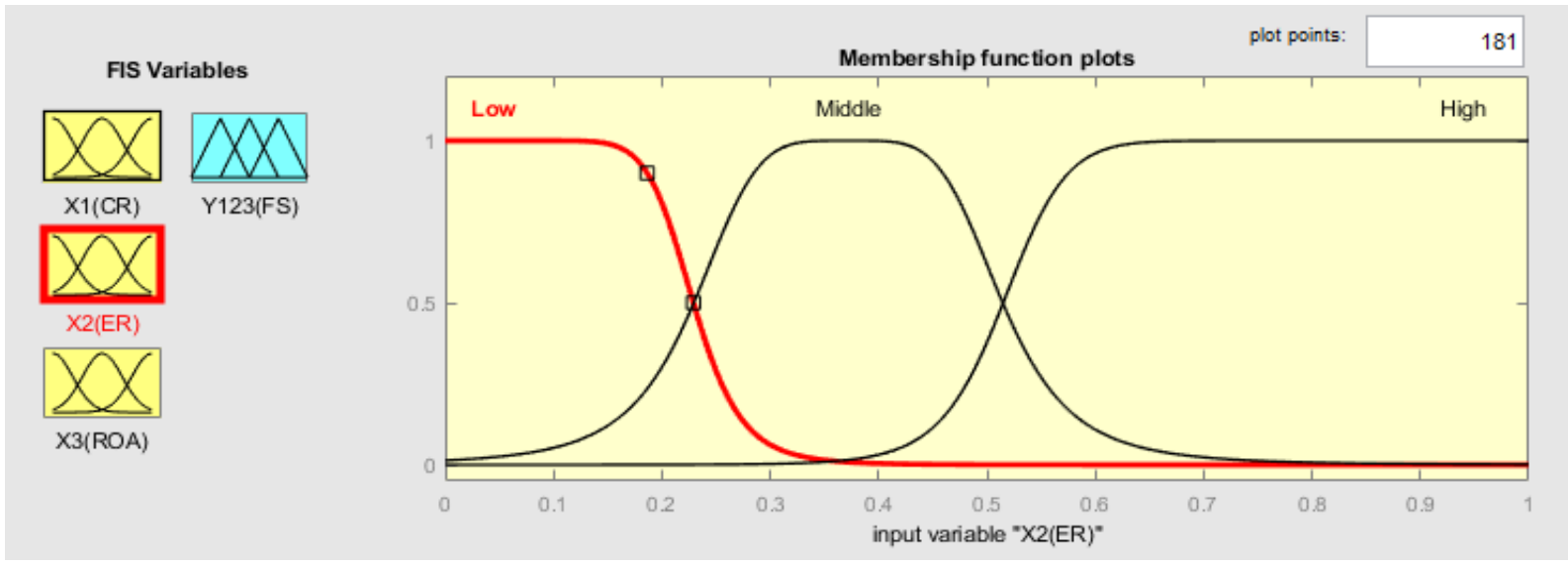

Figure 3. Membership function chart for input linguistic variable X2 ("Equity Ratio (ER)")

degree of Current Ratio, Middle - (satisfactory) degree of Current Ratio, High - (excellent) degree of Current Ratio). This function is a bell-shaped one and has value rate $[0 ; 2.5]$. Low membership function which means unsatisfactory degree has parameters [0.8 4.9 0.0732], Middle membership function which means satisfactory degree has parameters $\left[\begin{array}{llll}0.415 & 2.492 & 1.29\end{array}\right]$, High membership function which means excellent degree has parameters [0.521 4.64 2.23].

Figure 3 introduces $X 2(E R)$ input variable which is an Equity Ratio and has three attributes (membership functions): Low - (unsatisfactory) degree of Equity Ratio, Middle - (satisfactory) degree of Equity Ratio, High - (excellent) degree of Equity Ratio. This function is a bell-shaped one and has value rate $[0 ; 1]$. Low membership function which means improper degree has parameters [ $\left.\begin{array}{llll}0.184 & 4.17 & 0.04511\end{array}\right]$, Middle membership function which means satisfactory degree has parameters $\left[\begin{array}{llll}0.1425 & 2.24 & 0.372\end{array}\right]$, High membership function which means exceeding degree has parameters [0.423 7.157 0.938].

Figure 4 introduces $X 3(R O A)$ input variable which is a Retern of Assets and has three attributes (membership functions): Low - (unsatisfactory) degree of
Retern of Assets, Middle - (satisfactory) degree of Retern of Assets, High - (excellent) degree of Retern of Assets. This function is a bell-shaped one and has value rate $[-1 ; 1]$. Low membership function which means insufficient degree has parameters [0.709 14.74-0.703], Middle membership function which means resposive degree has parameters [ $\left[\begin{array}{llll}0.0647 & 1.4 & 0.07394\end{array}\right]$, High membership function which means outstanding degree has parameters [0.5443 12.2 0.683].

Figure 5 introduces output variable Y123 ("Financial Security Indicator (FS)") and has three attributes (membership functions): Low - (unsatisfactory) and has parameters [0.237 3.756 0.063], Middle - (satisfactory) and has parameters $\left[\begin{array}{lll}0.198 & 2.5 & 0.5001\end{array}\right]$, High (excellent) and has parameters [0.239 3.130 .937$]$. This function is a "bell"-shaped one and has value rate $[0 ; 1]$.

Based on the description of two input and one output variables we have defined $3^{3}=27$ fuzzy rules for the output variable conclusion.

Fuzzy logic rules are laid out as follows:

Rule 1: If (X1(CR) is Low) and (X2(ER) is Low) and (X3(ROA) is Low) then (Y123(FS) is Low);

Rule 2: If (X1(CR) is Low) and (X2(ER) is Middle) and (X3(ROA) is Low) then (Y123(FS) is Low); 


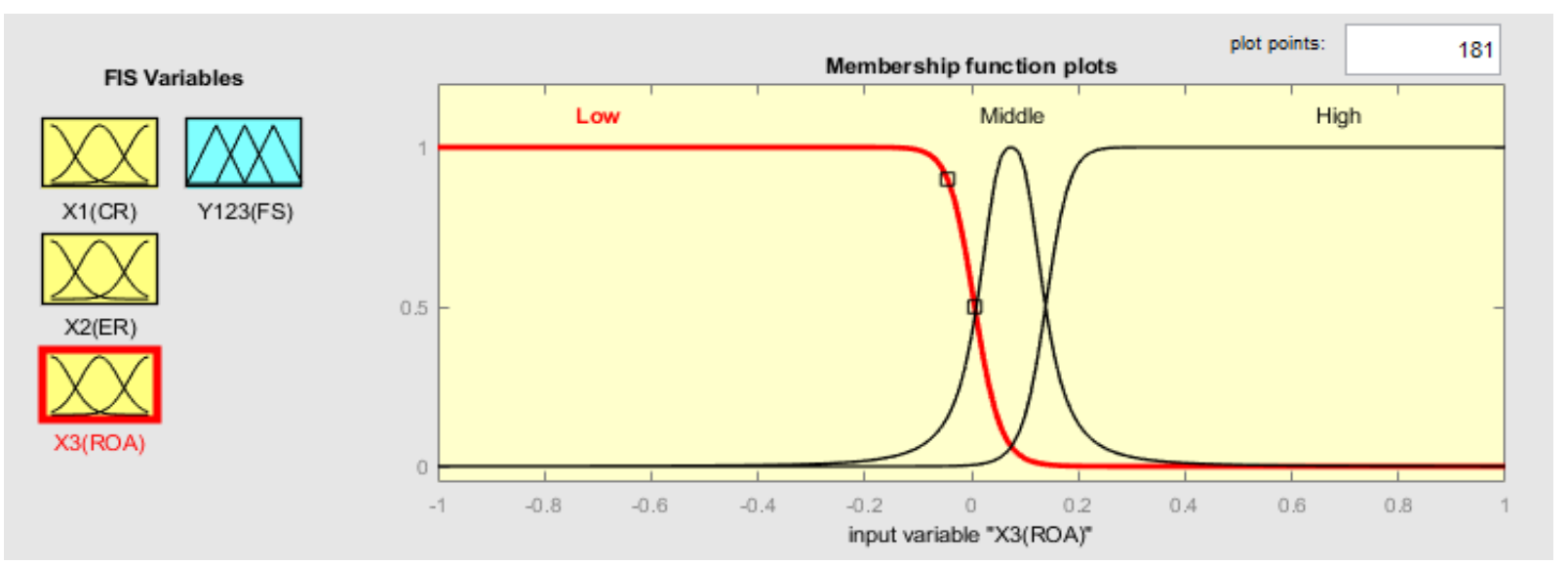

Figure 4. Membership function chart for input linguistic variable X3 ("Return on Assets (ROA)")

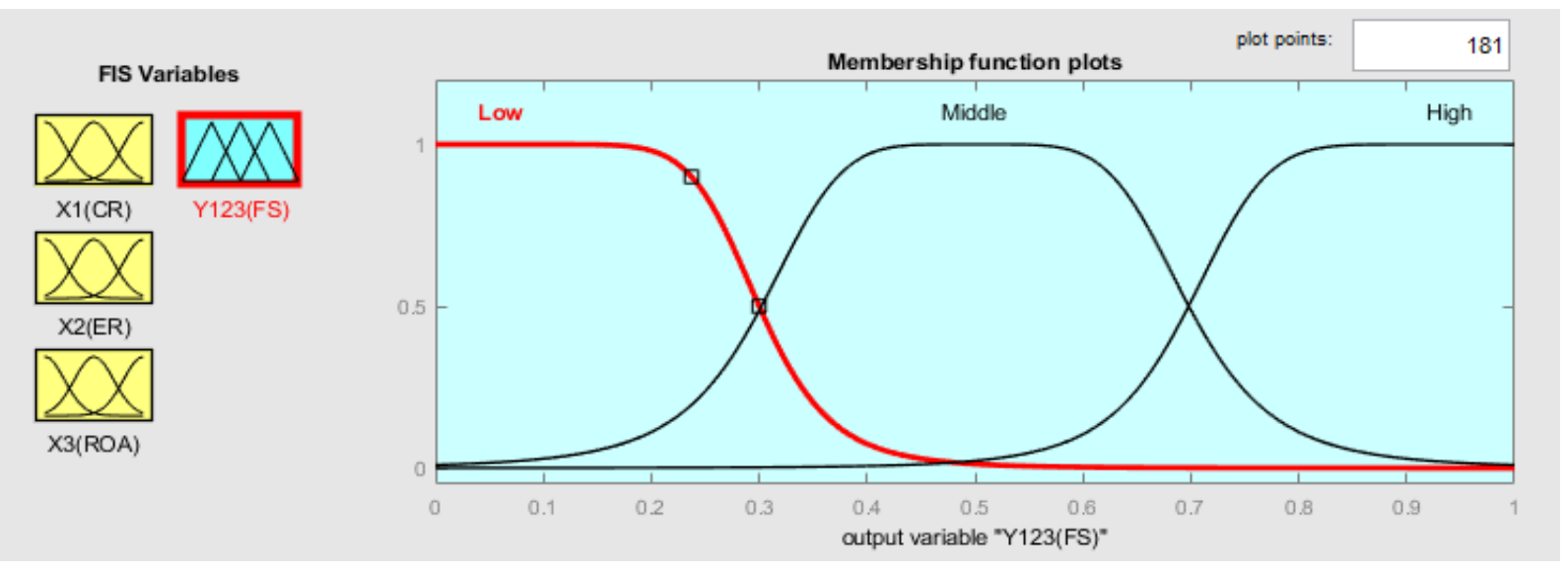

Figure 5. Membership function chart for output linguistic variable Y123 ("Financial Security Indicator (FS)")

Rule 3: If (X1(CR) is Low) and (X2(ER) is High) and (X3(ROA) is Low) then (Y123(FS) is Low);

Rule 4: If (X1(CR) is Middle) and (X2(ER) is Low) and (X3(ROA) is Low) then (Y123(FS) is Low);

Rule 5: If (X1(CR) is Middle) and (X2(ER) is Middle) and (X3(ROA) is Low) then (Y123(FS) is Middle);

Rule 6: If (X1(CR) is Middle) and (X2(ER) is High) and (X3(ROA) is Low) then (Y123(FS) is Middle);

Rule 7: If (X1(CR) is High) and (X2(ER) is Low) and (X3(ROA) is Low) then (Y123(FS) is Middle);

Rule 8: If (X1(CR) is High) and (X2(ER) is Middle) and (X3(ROA) is Low) then (Y123(FS) is Middle);

Rule 9: If (X1(CR) is High) and (X2(ER) is High) and (X3(ROA) is Low) then (Y123(FS) is Middle);

Rule 10: If (X1(CR) is Low) and (X2(ER) is Low) and (X3(ROA) is Middle) then (Y123(FS) is Low);

Rule 11: If (X1(CR) is Low) and (X2(ER) is Middle) and (X3(ROA) is Middle) then (Y123(FS) is Middle);

Rule 12: If (X1(CR) is Low) and (X2(ER) is High) and (X3(ROA) is Middle) then (Y123(FS) is Middle);

Rule 13: If (X1(CR) is Middle) and (X2(ER) is Low) and (X3(ROA) is Middle) then (Y123(FS) is Middle);

Rule 14: If (X1(CR) is Middle) and (X2(ER) is Middle) and (X3(ROA) is Middle) then (Y123(FS) is Middle);
Rule 15: If (X1(CR) is Middle) and (X2(ER) is High) and (X3(ROA) is Middle) then (Y123(FS) is Middle);

Rule 16: If (X1(CR) is High) and (X2(ER) is Low) and (X3(ROA) is Middle) then (Y123(FS) is Middle);

Rule 17: If (X1(CR) is High) and (X2(ER) is Middle) and (X3(ROA) is Middle) then (Y123(FS) is High);

Rule 18: If (X1(CR) is High) and (X2(ER) is High) and (X3(ROA) is Middle) then (Y123(FS) is High);

Rule 19: If (X1(CR) is Low) and (X2(ER) is Low) and (X3(ROA) is High) then (Y123(FS) is Low);

Rule 20: If (X1(CR) is Low) and (X2(ER) is Middle) and (X3(ROA) is High) then (Y123(FS) is Middle);

Rule 21: If (X1(CR) is Low) and (X2(ER) is High) and (X3(ROA) is High) then (Y123(FS) is Middle);

Rule 22: If (X1(CR) is Middle) and (X2(ER) is Low) and (X3(ROA) is High) then (Y123(FS) is Middle);

Rule 23: If (X1(CR) is Middle) and (X2(ER) is Middle) and (X3(ROA) is High) then (Y123(FS) is Middle);

Rule 24: If (X1(CR) is Middle) and (X2(ER) is High) and (X3(ROA) is High) then (Y123(FS) is High);

Rule 25: If (X1(CR) is High) and (X2(ER) is Low) and (X3(ROA) is High) then (Y123(FS) is Middle);

Rule 26: If (X1(CR) is High) and (X2(ER) is Middle) and (X3(ROA) is High) then (Y123(FS) is High); 
Rule 27: If (X1(CR) is High) and (X2(ER) is High) and (X3(ROA) is High) then (Y123(FS) is High).

The constructed fuzzy inference model allows you to estimate the integral Financial Security Indicator Y123(FS) depending on three variables, namely: the variable $X 1$, which is the Current Ratio (CR), the variable $X 2$, which is the ratio of autonomy (Equity Ratio (ER)) and the variable $X 3$, which is the coefficient of Return on Assets (ROA)).

The dependence of the output variable Y123 (FS), which is an indicator of the financial security of an enterprise, on the input variables $X 1(C R)$ and $X 2(E R)$ at different levels of fixed values $X 3(R O A)=-0.01$, $X 3(R O A)=0.05, X 3(R O A)=0.15$ and $X 3(R O A)=0.30$ is an infinity of values of $Y 123(F S)$, represented as a response surface constructed using the Surface Viewer visualizer (Figure $6 a, b, c, d$ ).

The dependence of the output variable Y123 (FS), which is an indicator of the financial security of an enterprise, on the input variables $X 1(C R)$ and $X 3(R O A)$ at different levels of fixed figures $X 2(E R)=0.1$, $X 2(E R)=0.3, \quad X 2(E R)=0.7$ and $X 2(E R)=0.7$ is an infinity of values of $Y 123(F S)$, represented as a response surface constructed using the Surface Viewer visualizer (Figure $7 a, b, c, d$ ).

The dependence of the output variable Y123 (FS), which is an indicator of the financial security of an enterprise, on the input variables $X 2(E R)$ and $X 3(R O A)$ at different levels of fixed values $X 1(C R)=0.2$,
$X 1(C R)=0.8, X 1(C R)=1.5$ and $X 1(C R)=2.5$ is an infinity of values of $Y 123(F S)$, represented as a response surface constructed using the Surface Viewer visualizer (Figure $8 a, b, c, d$ ).

Visualization of the "input-output" surface allows to define that output index $Y 123(F S)$, which is an indicator of the financial security of an enterprise, reaches its peak at the maximum values of the input parameters X1 (Current Ratio (CR)) and X2 (Equity Ratio (ER)) and X3 (Return on Assets (ROA)).

To determine the indicator of financial security of telecommunications enterprises, we will use previously justified indicators - financial coefficients. To do this, as an example, consider the primary financial statements for the enterprises "MEGA LINK", "TELEMIST" and "INTELLECT DNIPRO TELECOM". The main activity of the enterprises LLS "MEGA LINK" (USREOU (Unified State register of Enterprises and Organizations of Ukraine) code 33769837), LLC "TELEMIST" (USREOU code 34823863) and LLS "INTELLECT DNIPRO TELECOM" (USREOU code 35340503) is activities in the field of wired telecommunications (class 61.10 according to Clasifier of Economic Types of Activities - 2010).

Further research was conducted based on the accounting (financial) statements for these enterprises, which are publicly available, in particular, on the website zvitnist.com. The results of processing financial statement Data (Form 1 Balance Sheet and Form 2
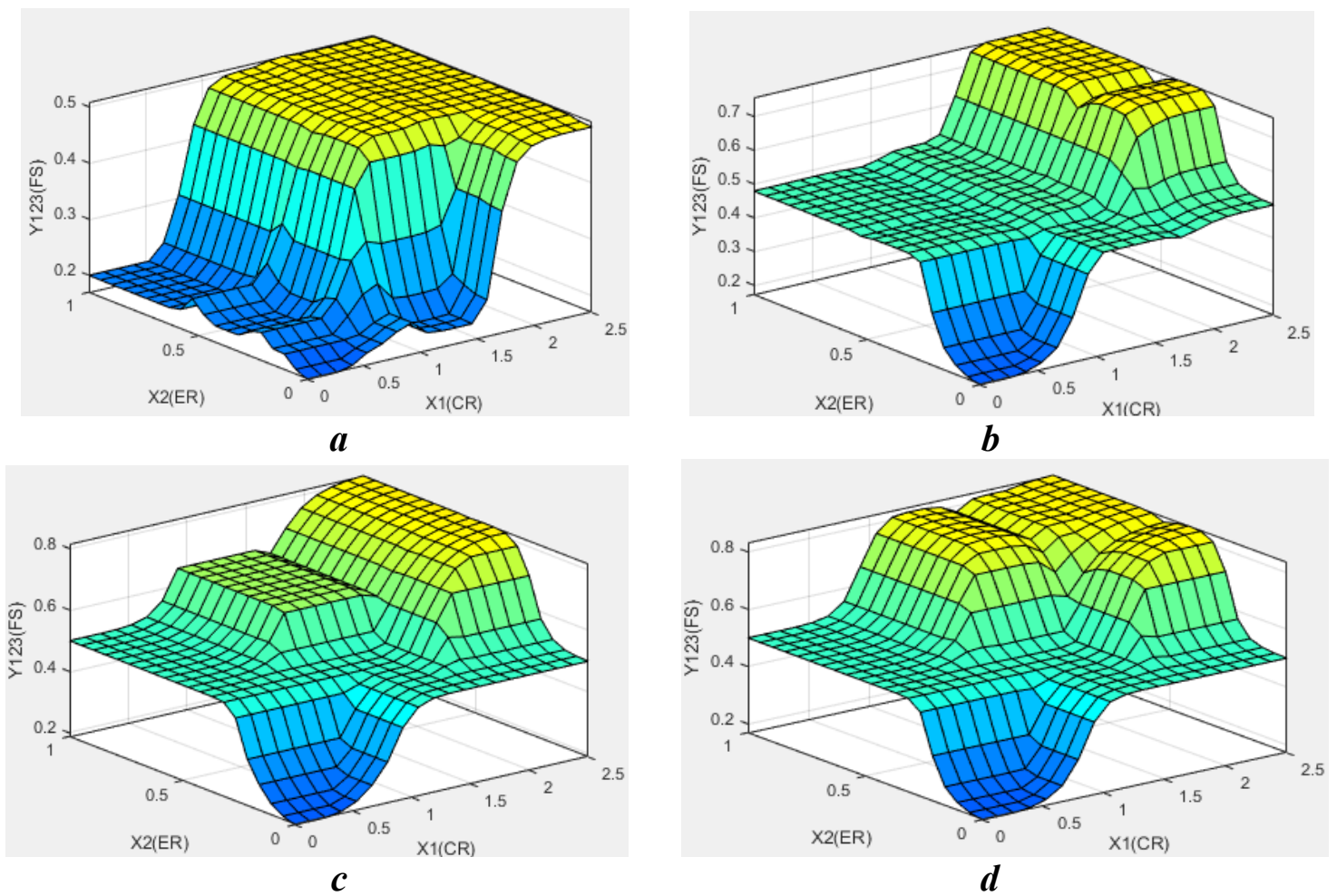

Figure 6. Depending of output variable $Y 123$ (FS) which is a degree of financial security indicator Y123 (FS) on the input argument $X 1(C R)$ and input parameter $X 2(E R)$ and at fixed value levels $X 3(R O A)=-0.1(a)$, $X 3(R O A)=0.05(b), X 3(R O A)=0.15(c)$ and $X 3(R O A)=0.30(d)$. Modelling results 

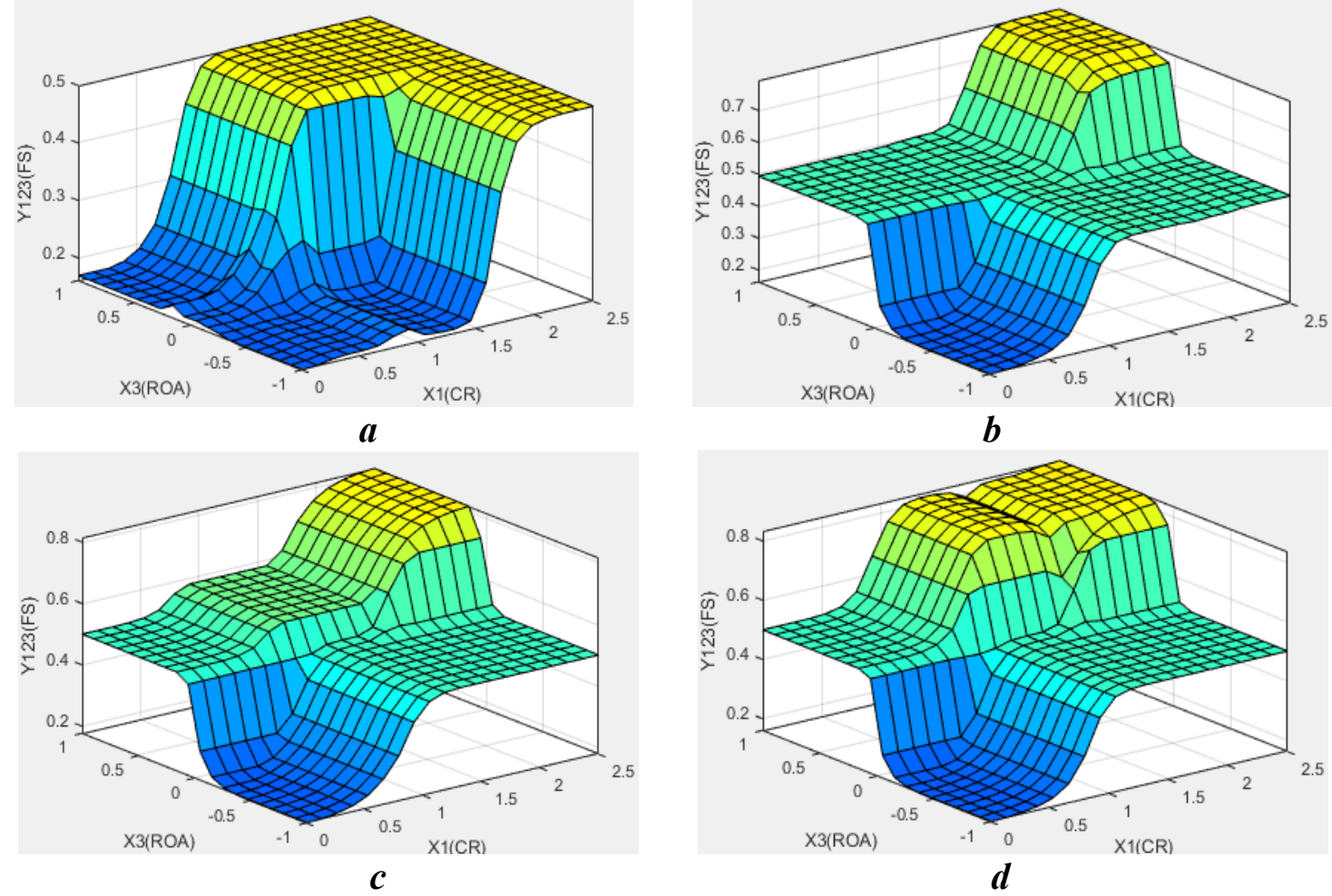

Figure 7. Depending of output parameter Y123(FS) which is a degree of financial security indicator Y123 (FS) on the input argument $X 1(C R)$ and input variable $X 3(R O A)$ and at fixed value levels $X 2(E R)=0.1(a)$, $X 2(E R)=0.3(b), X 2(E R)=0.5(c)$ and $X 2(E R)=0.7(d)$. Modelling results
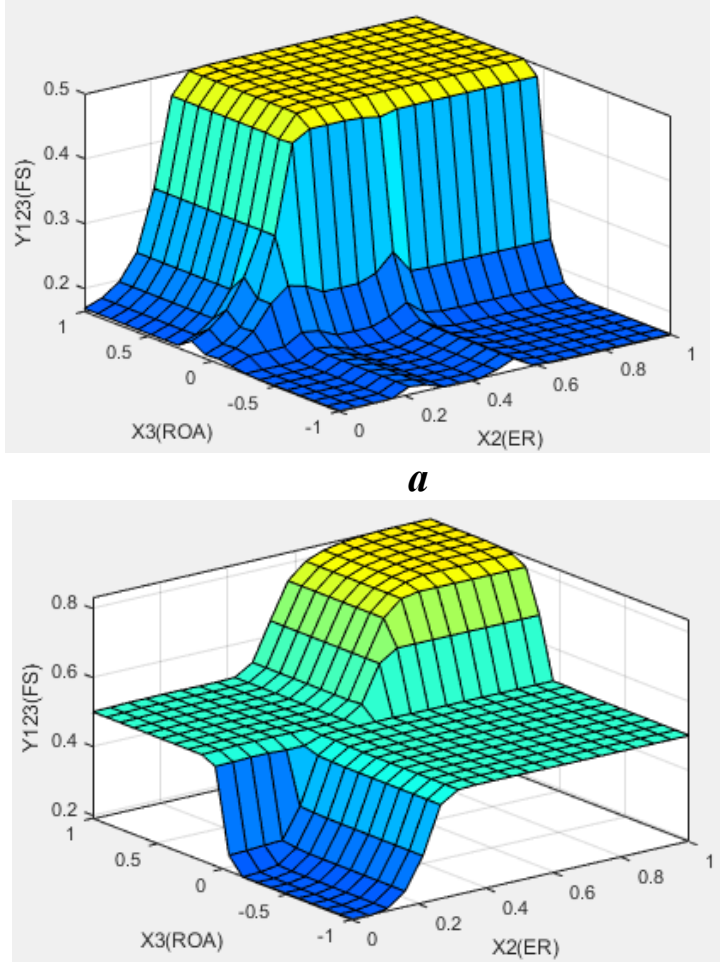

$c$
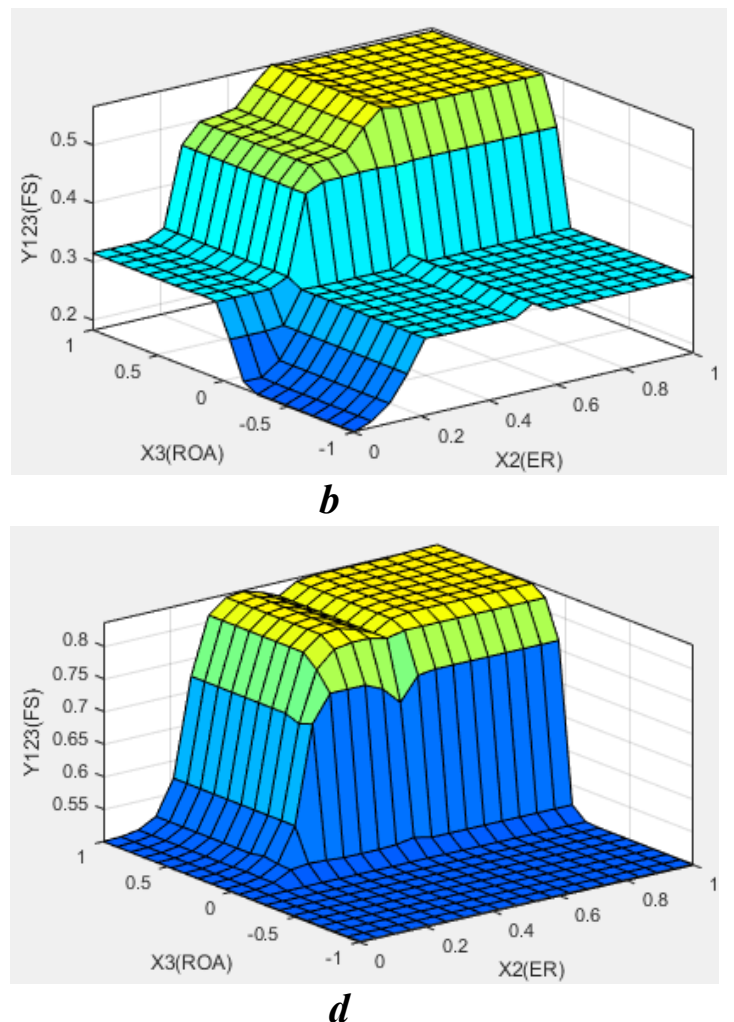

Figure 8. Depending of output variable Y123(FS) which is a degree of financial security indicator Y123 (FS) on the input parameter $X 2(E R)$ and input argument $X 3(R O A)$ and at fixed value levels $X 1(C R)=0.2(a)$, $X 1(C R)=0.8(b), X 1(C R)=1.5(c)$ and $X 1(C R)=2.5(d)$. Modelling results 
Table 3

Financial coefficients calculated based on the data of the primary financial statements, which are used as input data for the constructed fuzzy-logical model for assessing the financial security indicator of an enterprise

\begin{tabular}{|l|c|c|c|c|c|c|}
\hline \multirow{2}{*}{ Financial coefficients } & \multicolumn{6}{|c|}{ Value of financial coefficients } \\
\cline { 2 - 7 } & \multicolumn{2}{|c|}{ LLC "MEGA LINK" } & \multicolumn{2}{|c|}{ LLC "TELEMIST" } & \multicolumn{2}{c|}{ LLC "INTELLECT DNIPRO TELECOM" } \\
\cline { 2 - 7 } & 2019 year & 2020 year & 2019 year & 2020 year & 2019 year & 2020 year \\
\hline Current Ratio (CR) & 0.65 & 0.49 & 1.50 & 0.00 & 1.24 & 1.52 \\
\hline Equity Ratio (ER) & 0.35 & 0.30 & -3.19 & -338.09 & 0.16 & 0.25 \\
\hline Return on Assets (ROA) & 0.128 & 0.111 & -6.128 & -79.6 & 0.013 & 0.003 \\
\hline
\end{tabular}

Statement of Financial Results) in the form of financial coefficients are presented in Table 3.

For the LLC "MEGA LINK" enterprise from the data in Table 3 it is possible to observe a decrease in the company's financial independence, as evidenced by the dynamics of the financial autonomy coefficient. At the end of 2020, the company is able to independently finance $30.35 \%$ of its assets. The current liquidity value is below the regulatory limit $(<1.5)$, which may indicate the probability of solvency loss in the near future.

The value of the financial autonomy coefficient for the LLC "TELEMIST" enterprise in 2019 and 2020 is negative. This actually indicates a lack of financial independence. This company does not have its own funds to repay its liabilities, and the decrease in the financial autonomy ratio in 2020 compared to 2019 means a deepening of financial dependence in the reporting year. The financial condition of the enterprise of LLC "TELEMIST" can be characterized as extremely unstable, since the debt of the company exceeds the amount of its assets.

The dynamics of the financial autonomy coefficient indicates an increase in the company's financial independence for the LLC "INTELLECT DNIPRO TELECOM" enterprise. At the end of 2020, the company is able to independently finance $25.29 \%$ of its assets. The current liquidity value is above the regulatory limit (1.5), which indicates a low probability of solvency loss in the near future.

The last stage of building a fuzzy expert system is to determine the financial security indicator of the enterprise Y123(FS). The results of visualizing the calculation in the Matlab environment are presented using the Rule Viewer visualizer (Figures 9, 10 and 11).

The fuzzy inference rule viewer allows you to visualize the fuzzy output process and get the result.
These figures display the corresponding membership function, its cross-section level (for input variables), and the contribution of the individual membership function to the overall result (for the output variable). To estimate the financial condition using the fuzzy inference model, the values of the input variables and the result of the evaluation of enterprise financial security indicator Y123(FS) are set in Rule Viewer (top line in Figures 9, 10 and 11).

For the 2019 LLC "MEGA LINK" companies, the left column in Figure $9(a)$ represents 27 defined fuzzy rules, the next three columns show the values $X 1(C R)=10.6, X 2(E R)=0.35$, and $X 3(R O A)=0.128$ for the values of the input variables. The value Y123 (FS) is shown in the right column for each fuzzy rule as the level of the enterprise's financial security indicator. For these inputs, the output value of the financial security indicator is $Y 123(E S)=0.50$.

Table 4 shows the results of determining the enterprise financial security indicator Y123(FS) for the three telecommunications companies studied.

According to Table 4 it is reasonable to conclude that the level of financial security of the enterprises of LLC "MEGA LINK" and LLC "INTELLECT DNIPRO TELECOM" can be characterized by the linguistic term "medium level" or "satisfactory level", and the level of financial security of the enterprise of LLC "TELEMIST" can be characterized by the linguistic term "low level" or "unsatisfactory level".

\section{Conclusions}

Summing up the above, it should be stated that to assess the level of the financial security indicator of an enterprise, the fuzzy set method is considered the most effective in comparison with linear models because

Table 4

Enterprise financial security indicator Y123 (FS), determined based on the results of the fuzzy-logical expert system for the studied enterprises

\begin{tabular}{|l|c|c|c|c|c|c|}
\hline \multirow{2}{*}{\multicolumn{1}{|c|}{ Indicator }} & \multicolumn{6}{|c|}{ Value of the enterprises' financial security indicator } \\
\cline { 2 - 7 } & \multicolumn{2}{|c|}{ LLC "MEGA LINK" } & \multicolumn{2}{c|}{ LLC "TELEMIST" } & \multicolumn{2}{|c|}{ LLC "INTELLECT DNIPRO TELECOM" } \\
\cline { 2 - 7 } & 2019 year & 2020 year & 2019 year & 2020 year & 2019 year & 2020 year \\
\hline $\begin{array}{l}\text { Indicator of enterprise } \\
\text { financial security (Y123(FS)) }\end{array}$ & 0.500 & 0.493 & 0.246 & 0.161 & 0.403 & 0.439 \\
\hline
\end{tabular}


Vol. 7 No. 4, 2021

BALTIC JOURNAL OF ECONOMIC STUdies
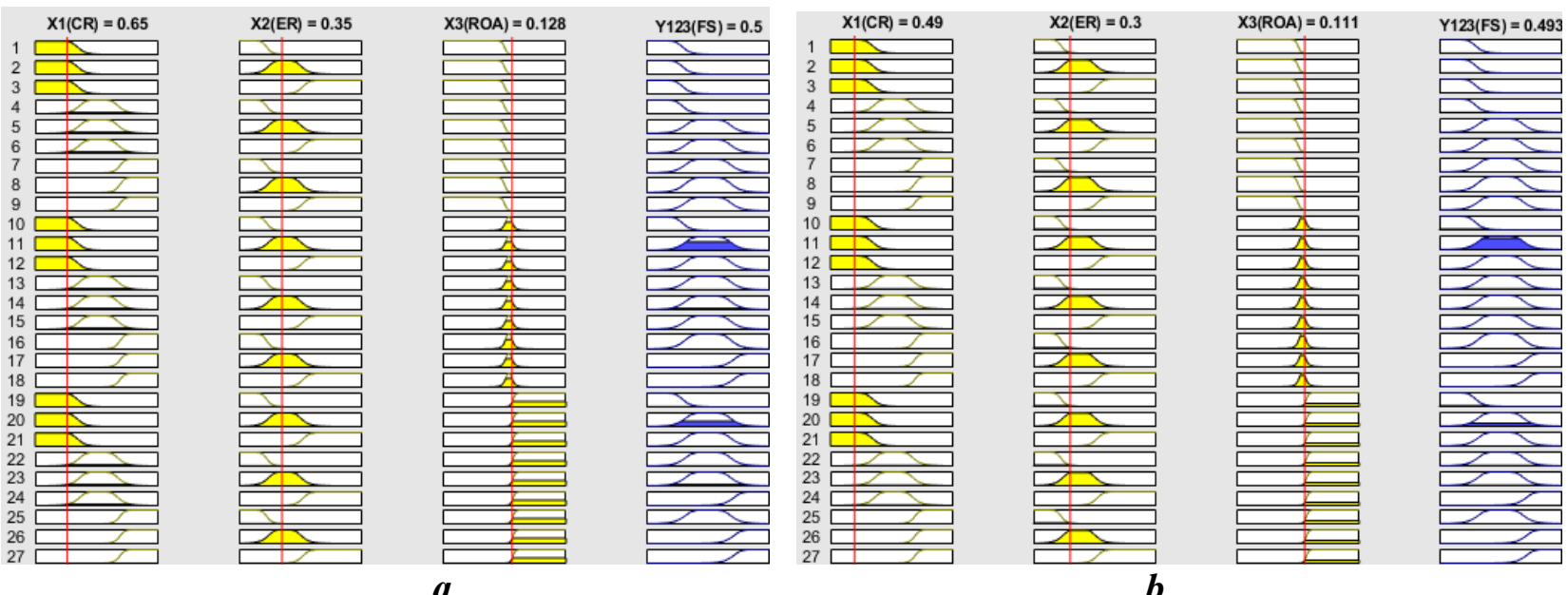

Figure 9. Implementation of Mamdani fuzzy conclusion in Fuzzy Logic Toolbox software of Matlab environment by MathWorks company for evaluation of a degree of financial security indicator Y123 (FS) for LLC "MEGA LINK" in 2019 year (a) and in 2020 year (b)
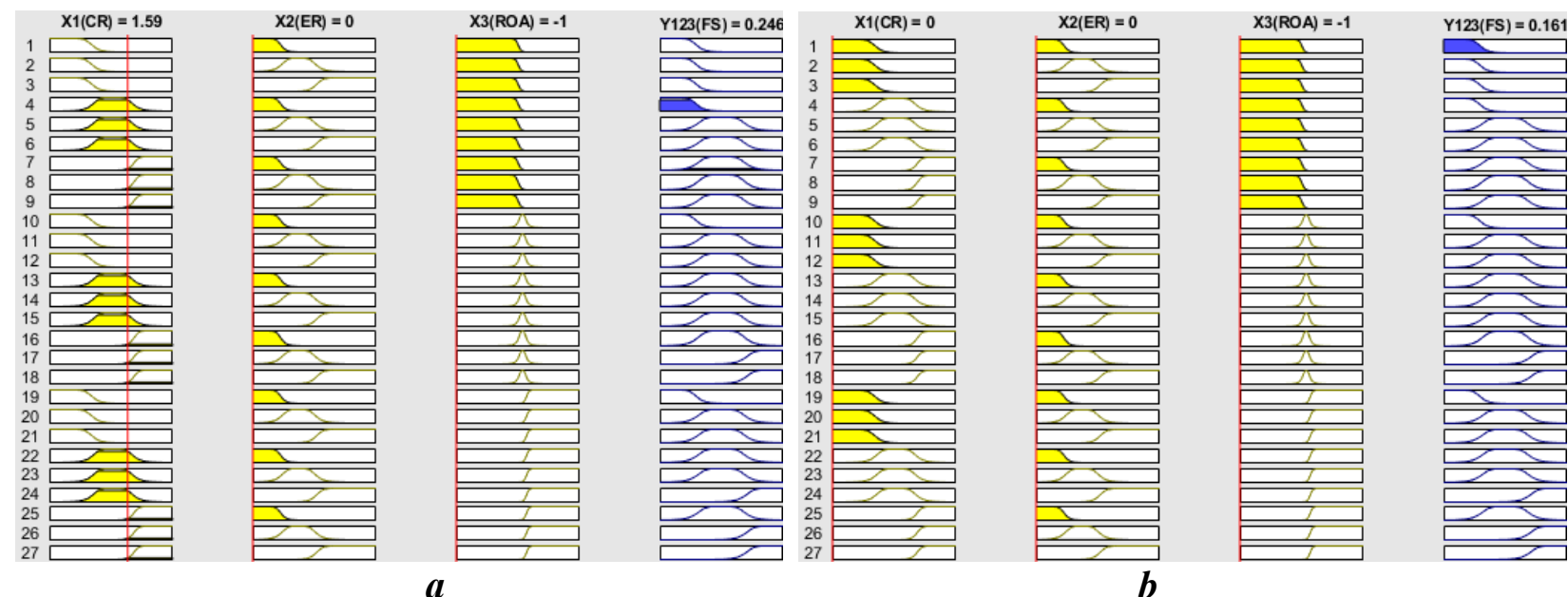

Figure 10. Implementation of Mamdani fuzzy conclusion in Fuzzy Logic Toolbox software of Matlab environment by MathWorks company for evaluation of a degree of financial security indicator Y123 (FS) for LLC "TELEMIST" in 2019 year $(a)$ and in 2020 year $(b)$
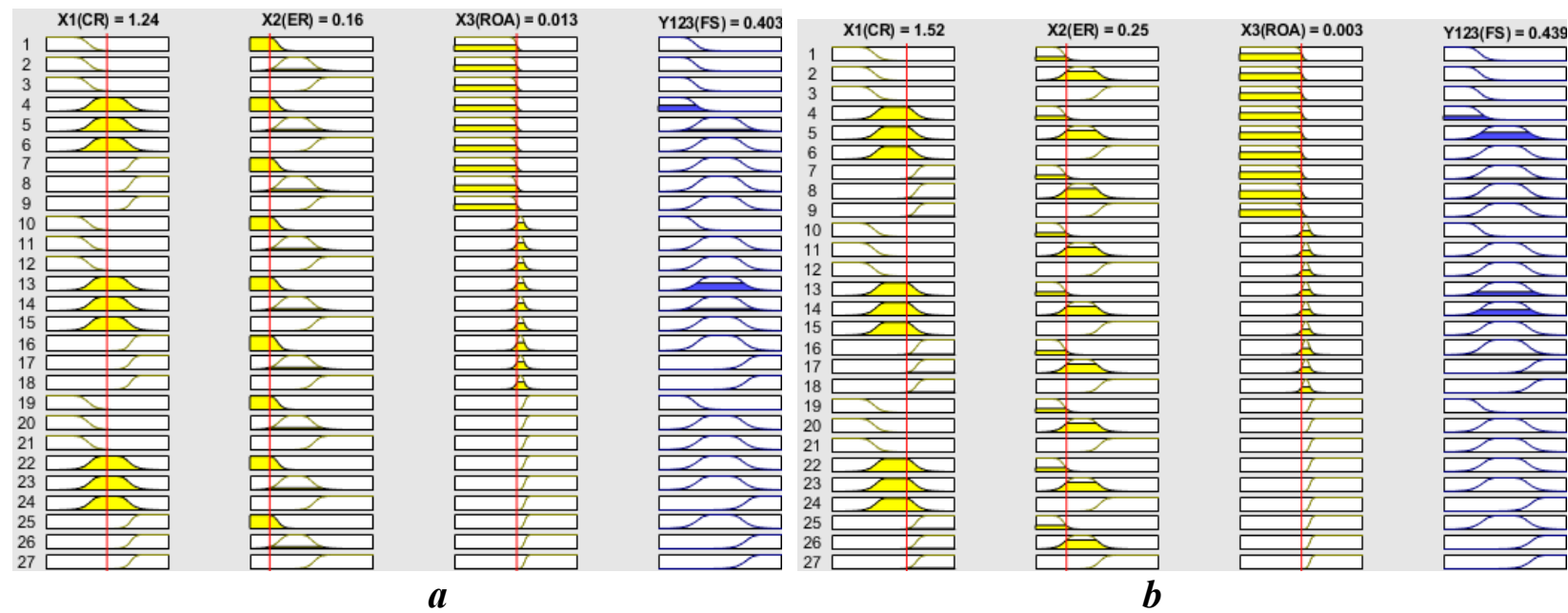

Figure 11. Implementation of Mamdani fuzzy conclusion in Fuzzy Logic Toolbox software of Matlab environment by MathWorks company for evaluation of a degree of financial security indicator Y123 (FS) for LLC "INTELLECT DNIPRO TELECOM" in 2019 year $(a)$ and in 2020 year $(b)$ 
it takes into account the uncertainty of the internal and external environment of the enterprise as much as possible. The fuzzy model theoretically allows you to use a significant number of input parameters, both quantitative and qualitative. However, the specific choice of parameters should be justified by their weight, on the one hand, and the complexity of collecting data necessary to evaluate the financial security of the enterprise, on the other hand.

To implement a fuzzy-logical approach to determining the integral indicator of financial security of an enterprise (FS), three financial coefficients are involved that characterize solvency (Current Ratio $(C R)$ ), financial independence (Equity Ratio (ER)) and profitability of total assets of the enterprise (Return on Assets (ROA)) and affect the target indicator.
Fuzzy logic model developed for evaluation of a degree of financial security of telecommunications enterprises is executed in the following phases: 1) engagement of three financial coefficients as input variables of the model, which are calculated on the basis of statistical and financial reporting data; 2) selection of membership function parameters and type for three input variables and for the output one; 3 ) development of the system of 27 rules; 4) calculation of an indicator of financial security of the enterprise using Mamdani fuzzy conclusion; 5) verification of the model adequacy.

The authors' next research will be aimed at improving the fuzzy-logical model for assessing the financial security indicator of an enterprise and expanding the scope of application of the proposed model to enterprises in other sectors of the national economy.

\section{References:}

Altman, E. I. (1968). Financial Ratios, Discriminant Analysis and the Prediction of Corporate Bankruptcy. The Journal of Finance, 4, 589-609.

Blank, Y. A. (2004). Upravlenye fynansovoi bezopasnostiu predpryiatyia [Financial security management of the enterprise]. Kyiv: Elga, Nika-Center.

Chaika, T. Iu., Loshakova, S. Ie., \& Vodoriz, Ya. S. (2018). Rozrakhunok koefitsiientiv likvidnosti za balansom, urakhuvannia finansovykh i vyrobnychykh osoblyvostei pidpryiemstva pid chas zdiisnennia koefitsiientnoho analizu likvidnosti [Calculation of liquidity ratios on the balance sheet, taking into account the financial and production characteristics of the enterprise when performing a coefficient analysis of liquidity]. Ekonomika ta suspilstvo [Economy and Society], 12, 900-908.

Davydenko, N. M. (2017). Investytsiina pryvablyvist pidpryiemstv [Investment attractiveness of enterprises]. Aktualni problemy rozvytku ekonomiky rehionu [Investment attractiveness of enterprises], 13(1), 59-68.

Diyazitdinova, A. R., \& Saprikina, A. A. (2018). Primenenie nechyotko-mnozhestvennogo metoda pri ocenke finansovoj ustojchivosti infokommunikacionnyh kompanij [Fuzzy logic method for rating financial standing of infocommunication company]. Infokommunikacionnye tehnologii [Infocommunication technologies], 16(3), 310-317.

Herasymenko, S. S., \& Holovach, N. A. (2003). Peredbachennia finansovoho stanu pidpryiemstva pry otsintsi yoho zdatnosti do prodovzhennia diialnosti [Predicting the financial condition of an enterprise when assessing its ability to continue operating]. Actual problems of the economy, 4, 2-4.

Hladchenko, T. M. (2001). Ekonomichna bezpeka pidpryiemnytskoi diialnosti [Economic security of entrepreneurial activity]. Aktualni problemy mizhnarodnykh vidnosyn [Current problems of international relations] Collection of scientific works, issue 26. Kyiv: VPC "Kiev University", Institute of international relations.

Kampo, H. M., Dochynets, N. M., \& Havrylets, O. V. (2017). Otsinka finansovoi stiikosti pidpryiemstv Ukrainy [Assessment of financial stability of Ukrainian enterprises]. Scientific Bulletin of Uzhgorod university. Economics series, issue 1(49), t. 1, pp. 150-158.

Korpan, O. V. (2017). Metody otsiniuvannia rivnia finansovoi bezpeky pidpryiemstva [Methods for assessing the level of financial security of an enterprise]. Efektyvna ekonomika [Efficient economy], no. 1. Available at: http://www.economy.nayka.com.ua/?op=1\&z=5401 (accessed 15 August 2021).

Korol, T., \& Korodi, A. (2012). An evaluation of effectiveness of fuzzy logic model in predicting the business bankruptcy. Institute for Economic Forecasting, 3, 92-107.

Krakos, Yu. B., \& Razghon, R. O. (2008). Upravlinnia financovoiu bezpekoiu pidpryiemstv [Managing the financial security of enterprises]. Ekonomika ta upravlinnia pidpryiemstvamy mashynobudivnoi haluzi: problemy teorii ta praktyky [Economics and management of machine-building enterprises: problems of theory and practice], $1(1), 86-97$.

Myachin, V. H., \& Kutsyns'ka, M. V. (2015). Vyznachennia priorytetnosti pokaznykiv finansovoho stanu, obranykh dlia otsinky ryzyku bankrutstva promyslovykh pidpryiemstv metodom nechitkykh mnozhyn [Determining the priority of Financial Condition Indicators selected for assessing the risk of bankruptcy of industrial enterprises using the fuzzy set method]. Naukovyi visnyk Mizhnarodnoho humanitarnoho universytetu [Scientific Bulletin of the International Humanitarian University], 14, 159-163.

Parshyna, O. A., Myachin V. H., \& Kutsyns'ka, M. V. (2016). Obhruntuvannia ta pobudova funktsii nalezhnosti $\mathrm{v}$ nechitko-lohichnii modeli otsinky finansovoho stanu pidpryiemstva ta ryzyku nastannia yoho bankrutstva [Rationale and construction of membership functions in a fuzzy-logic model for assessment of the enterprise financial condition and risk of its bankruptcy]. Visnyk ONU imeni Mechnykova [Bulletin of the Mechnikov ONU], vol. 21, issue 5(48), pp. 86-91. 
Vol. 7 No. 4, 2021

Pegat, A. (2009). Nechetkoe modelirovanie i upravlenie [Fuzzy modeling and control]. Moscow: BINOM. Laboratoriya znanij.

Sosnovska, O. O. (2019). Systema ekonomichnoi bezpeky pidpryiemstv zviazku: monohrafiia [Innovative development and economic security of industrial enterprises: problems of integrated management: monograph]. Kyiv: Tsentr uchbovoi literatury.

Starynets, O. H. (2018). Otsinka finansovoho stanu telekomunikatsiinoho pidpryiemstva v systemi antykryzovoho upravlinnia [Estimation of the financial state of telecommunication enterprise in systems of anticrisis management]. Hlobalni ta natsionalni problemy ekonomiky [Global and national economic problems], 21, 407-411.

Tereshchenko, O. O. (2004). Antykryzove finansove upravlinnia na pidpryiemstvi [Anti-crisis financial management at the enterprise]. Kyiv: KNEU.

Toffler, R., \& Tishaw, H. (1977). Going, going, gone - fourfactors which predict. Accountancy. March. P. 50-54.

Voloshchuk, L. O. (2015). Innovatsiinyi rozvytok ta ekonomichna bezpeka promyslovykh pidpryiemstv: problemy kompleksnoho upravlinnia: monohrafiia [Innovative development and economic security of industrial enterprises: problems of integrated management: monograph]. Odesa: Bondarenko M. O.

Yelisieieva, O. K., \& Simon, H. S. (2016). Analiz hroshovykh potokiv firmy yak skladova formuvannia stratehii staloho rozvytku [Analysis of a firm's cash flows as a component of forming a sustainable development strategy]. Business-inform, 12, 380-384. 